\title{
Experimental Installation for Determination of Attenuation Coefficient of Permanent Magnetic Field by Protective Materials
}

\author{
V.M. Fedosyuk \\ Scientific and Practical Materials Research Center of the National Academy of Sciences of Belarus, \\ P. Brovki str., 19, Minsk 220072, Belarus
}

Received 19.01.2021

Accepted for publication 22.02.2021

\begin{abstract}
The permanent magnetic field in addition to electromagnetic radiation has a significant effect on performance of devices. This is particularly true for highly sensitive precision measuring equipment, such as, for example, magnetometers or photomultiplier tubes. In this regard a new high-performance materials for protection against permanent fields and electromagnetic radiation need to be developed. The purpose of this paper is a development of a hardware and software complex for high-precision determination of permanent magnetic field attenuation coefficient and certification of protective materials.

This paper describes an experimental installation for determining the attenuation coefficient of a permanent magnetic field using materials and coatings on standard package for electronic equipment. The installation ensures a uniform magnetic field flow in the measurement volume. The advantage of the measuring device is the ability to measure magnetic field in three coordinates due to the use of three pairs of Helmholtz coils and a three-dimensional Hall sensor. The software will enable to control of the magnetic field in all three directions, simulating the real operating conditions of devices that require protection from such influences. In addition, a movable positioning system makes it possible to compensate for the Earth's magnetic field, which increases the accuracy of estimating the attenuation coefficient by protective materials in weak magnetic field.

An alternative use of the capabilities of the installation is to test the performance of the devices in a permanent magnetic field and evaluate the electromagnetic compatibility. Experimental results of the work includes determination of the magnetic field attenuation coefficient using standard photomultiplier tube package made of electrolytically deposited permalloy and the sheet of annealed permalloy. Thus, the effect of annealing and closed magnetic circuit on the degree of weakening of the magnetic field is shown. It has been demonstrated that annealing which causes a significant increase in the magnetic permeability promotes an effective attenuation of weak magnetic fields (up to $1 \mathrm{mT}$ ). In magnetic fields with an induction of $1 \mathrm{mT}$ or more, effective attenuation is provided by a closed magnetic circuit.
\end{abstract}

Keywords: Helmholtz coils, constant magnetic field, attenuation coefficient, permalloy.

DOI: $10.21122 / 2220-9506-2021-12-1-7-12$

\begin{tabular}{ll}
\hline Адрес для переписки: & Address for correspondence: \\
Федосюк В.М. & Fedosyuk V.M. \\
НПЦНАН Беларуси по материаловедению, & Scientific and Practical Materials Research Center of the National \\
ул. П. Бровки, 19, & Academy of Sciences of Belarus, \\
2. Минск 220072, Беларусь & P. Brovki str., 19, Minsk 220072, Belarus \\
e-таil: fedosyuk@physics.by & e-mail: fedosyuk@physics.by \\
\hline Для цитирования: & For citation: \\
V.M. Fedosyuk. & V.M. Fedosyuk. \\
Experimental Installation for Determination of Attenuation & Experimental Installation for Determination of Attenuation \\
Coefficient of Permanent Magnetic Field by Protective Materials. & Coefficient of Permanent Magnetic Field by Protective Materials. \\
Приборы и методы измерений. & Devices and Methods of Measurements. \\
2021. - Т. 12, № 1.- С. 7-12. & 2021, vol. 12, no. 1, pp. 7-12. \\
DОI: $10.21122 / 2220-9506-2021-12-1-7-12$ & DOI: 10.21122/2220-9506-2021-12-1-7-12 \\
\hline
\end{tabular}




\section{Экспериментальная установка для определения коэффициента ослабления постоянного магнитного поля защитными материалами}

\section{В.М. Федосюк}

Научно-практический центр Национальной академии наук Беларуси по материаловедению, ул. П. Бровки, 19, г. Минск 220072, Беларусь

Поступила 19.01.2020

Принята к печати 22.02.2021

Постоянное магнитное поле наряду с электромагнитным излучением оказывает существенное влияние на рабочие характеристики и работоспособность приборов. Особенно это касается высокочувствительного прецизионного измерительного оборудования, такого как, например, магнитометры или фотоэлектронные умножители. В связи с этим возникает необходимость разработки новых высокоэффективных материалов для защиты от воздействия постоянного магнитного поля и электромагнитного излучения. Целью данной работы являлась разработка программно-аппаратного комплекса для высокоточного определения коэффициента ослабления постоянного магнитного поля и аттестации защитных корпусов.

В работе описана измерительная установка для определения коэффициента ослабления постоянного магнитного поля с помощью материалов и покрытий на стандартных корпусах. Установка обеспечивает однородное магнитное поле во всём измерительном объёме. Отличие измерительной установки от существующих стендов заключается в возможности проведения измерений в трёх координатах благодаря использованию трёх пар катушек Гельмгольца и трёхкоординатного датчика Холла. Программное обеспечение позволит управлять магнитным полем во всех трёх направлениях, моделируя реальные условия эксплуатации приборов, требующих защиты от таких воздействий. Кроме того, подвижная система позиционирования в пространстве позволяет компенсировать магнитное поле Земли, что повышает точность оценки коэффициента ослабления магнитного поля защитными материалами в слабых полях.

Альтернативным вариантом использования возможностей установки является проверка рабочих характеристик приборов в условиях воздействия постоянного магнитного поля и оценка электромагнитной совместимости. Экспериментальная часть работы включает результаты определения коэффициента ослабления магнитного поля с помощью стандартных корпусов для фотоэлектронного умножителя, изготовленных из листового отожжённого пермаллоя и пермаллоя, осаждённого электролитически на алюминиевую подложку. Таким образом, показано влияние отжига и замкнутости магнитоконтура на степень ослабления магнитного поля. Установлено, что отжиг, вызывающий существенное повышение магнитной проницаемости, способствует эффективному ослаблению слабых магнитных полей (до 1 мТл). В магнитных полях с индукцией от 1 мТл эффективное ослабление обеспечивает замкнутый магнитоконтур.

Ключевые слова: катушки Гельмгольца, постоянное магнитное поле, коэффициент ослабления, пермаллой.

DOI: $10.21122 / 2220-9506-2021-12-1-7-12$

\begin{tabular}{ll}
\hline Адрес для переписки: & Address for correspondence: \\
Федосюк В.М. & Fedosyuk V.M. \\
НПЦ НАН Беларуси по материаловедению, & Scientific and Practical Materials Research Center of the National \\
ул. П. Бровки, 19, & Academy of Sciences of Belarus, \\
2. Минск 220072, Беларусь & P. Brovki str., 19, Minsk 220072, Belarus \\
e-таil: fedosyuk@physics.by & e-mail: fedosyuk@physics.by \\
\hline Для цитирования: & For citation: \\
V.M. Fedosyuk. & V.M. Fedosyuk. \\
Experimental Installation for Determination of Attenuation & Experimental Installation for Determination of Attenuation \\
Coefficient of Permanent Magnetic Field by Protective Materials. & Coefficient of Permanent Magnetic Field by Protective Materials. \\
Приборы и методы измерений. & Devices and Methods of Measurements. \\
2021. - Т. 12, № 1.- С. 7-12. & 2021, vol. 12, no. 1, pp. 7-12. \\
DОІ: 10.21122/2220-9506-2021-12-1-7-12 & DOI: 10.21122/2220-9506-2021-12-1-7-12 \\
\hline
\end{tabular}




\section{Introduction}

The problem of exposure to various types of electromagnetic fields on the equipment and systems, as well as living organisms is extremely important and multifaceted due to the complexity of interpretation of the processes of interaction of fields with the materials [1-3]. There are many fairly effective solutions for protection against electromagnetic radiation divided into active and passive protection methods [4-6]. The most difficult task is protection from exposure by static magnetic fields. This problem is acute for precision measuring equipment and space equipment [7] which is intensely exposed to constant and alternating magnetic fields. The physical principle of protection against magnetostatic effects consists in shunting the magnetic flux by a housing made from ferromagnetic material with high magnetic permeability [8-9]. The force lines of the external magnetic field will predominantly pass through the material with high magnetic permeability and will not affect the operation of the enclosed equipment. In connection with the above, active developments are underway in the field of creating materials and optimizing housing designs for effective weakening of magnetic flux and protection of sensitive electronics and equipment [10-14].

An important stage in the development of materials and housings is certification and determination of the degree of weakening of the magnetic field using a protective housing. The developers face the greatest number of difficulties when determining the shielding of weak magnetic fields from which it is necessary to protect, for example, photomultiplier tubes operating in outer space (of the orbit of the "MIR" station, the magnetic field induction is $0.4-0.6 \mathrm{mT}$ ). Difficulties in the development of measuring equipment are primarily related to the need to create a uniform and controlled magnetic flux as well as to compensate for the Earth's magnetic field to improve accuracy. Therefore the main goal of this work was to develop a software and hardware complex for high-precision determination of the attenuation coefficient of a constant magnetic field and certification of protective enclosures.

\section{Installation for determining the magnetostatic shielding effectiveness}

Device for determining the magnetic field attenuation coefficient should include the following capabilities:
- ensuring a uniform magnetic field throughout the entire volume of measurements;

- possibility of standard package for electronic equipment attestation;

- ability to carry out measurements at a magnetic field induction from 0.03 to $0.5 \mathrm{mT}$ for materials that weaken the magnetic field by 100 times, and in the range from 0.5 to $10 \mathrm{mT}$ for materials that weaken by 1000 times;

- compensation of the Earth's magnetic field when measuring in weak fields;

- ability to measure in three coordinates.

The problem of forming a uniform magnetic field and constant magnetic flux in a certain volume of space can be solved in many ways. Often for this permanent magnets are used between the poles of which a constant field is formed without the application of any energy. The main disadvantage of such a solution is the complexity of a controlled change in the magnitude of the magnetic field, since the magnitude of the magnetic induction for permanent magnets is determined exclusively by the remanent magnetization of the material and the distance between its poles.

It is advisable to create a weak and uniform magnetic field (up to $0.1 \mathrm{~T}$ ) with a variable value using solenoids or coils. It is better to use electromagnets to generate magnetic fields of greater magnitude with which you can obtain a high magnetization of the core with a relatively low current value or a coreless coil made of superconducting material.

Since an important criterion for a measuring device is to obtain a magnetic field with a high degree of homogeneity, the most promising solution seems to be the use of Helmholtz coils which substitute two solenoids located coaxially at a distance equal to their radius, as shown in Figure $1 a$. The coils diameter should be larger than the size of the area in which a uniform magnetic flux is required. Figure $1 b$ shows how the magnetic induction $B$ will change along the axis of the Helmholtz coils. The graph is plotted schematically in relative units where one corresponds to the maximum value of $B$. The magnetic induction at the midpoint on the axis between coils can be calculated using the equation (1):

$B=\left(\frac{4}{3}\right)^{3 / 2} \frac{\mu_{0} n I}{R}$,

where $\mu_{0}$ is the magnetic constant, $1.257 \cdot 10^{-6} \mathrm{~T} \cdot \mathrm{m} / \mathrm{A}$; $n$ is the number of turns of the coil; $I$ is the current flowing through the coil, $\mathrm{A} ; R$ is the radius of the coil, m. 

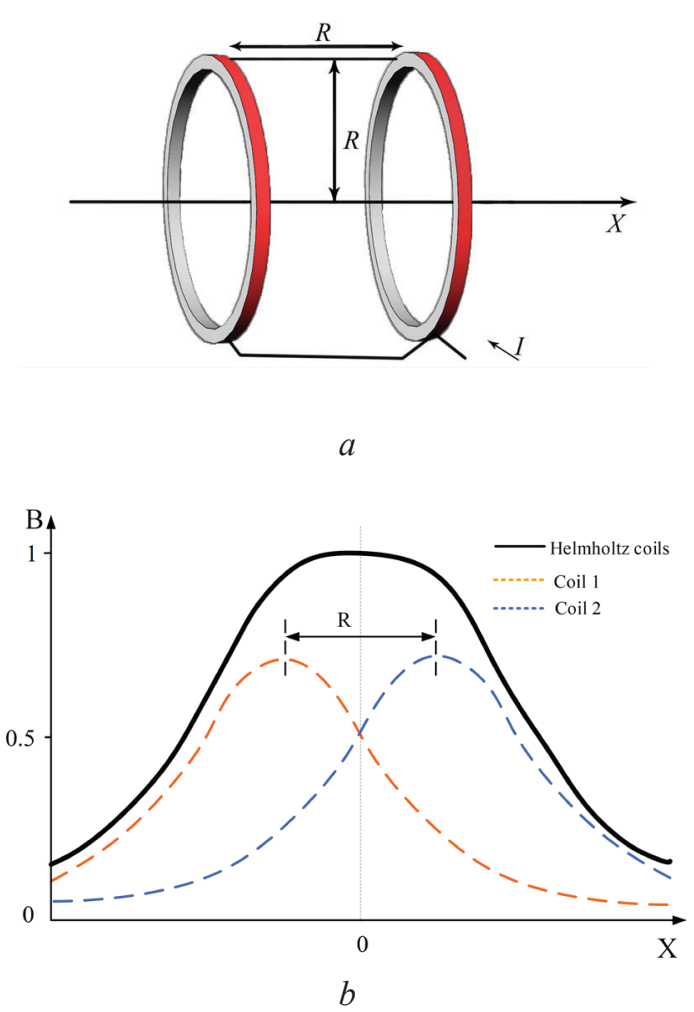

Figure 1 - Image of Helmholtz coils $(a)$ and a schematic graph of changes in the magnetic induction of Helmholtz coils $(b)$

For implementation of the comprehensive certification of protective enclosures for radio electronic equipment it is important to be able to control not only the magnitude of the magnetic field but also the direction of the magnetic flux. Therefore, the facility under development includes three pairs of Helmholtz rings with a diameter of 30,35 and $40 \mathrm{~cm}$ generating a constant magnetic field directed along the $X, Y$, and $Z$ axes, respectively. In this case, the magnetic flux $\Phi$ for each of the coils is numerically equal to the magnetic induction $B$ multiplied by the cross-sectional area of the coil $S$ in square meters (2):

$\Phi=B \cdot S$.

To register the magnitude of the magnetic field the installation uses a three-coordinate Hall sensor with ferrite concentrators of the magnetic strip installed at the intersection of the axes of the coils in such a way that the plane of the sensor crystal is perpendicular to the magnetic flux lines. The signal from the sensor is read by a nanovoltmeter. Figure 2 shows a diagram of an installation with two pairs of Helmholtz coils. The pairs of coils are connected to a direct current source during the flow of which a constant uniform magnetic field is created. The current strength is directly proportional to the magnetic field strength $H$, therefore, the coefficients $k_{I \rightarrow H}$ for recalculating the current strength into the magnetic field induction according to formula (3) for each pair of coils have been experimentally established. Their values are presented in Table.

$H=k_{I \rightarrow H} \cdot I$.

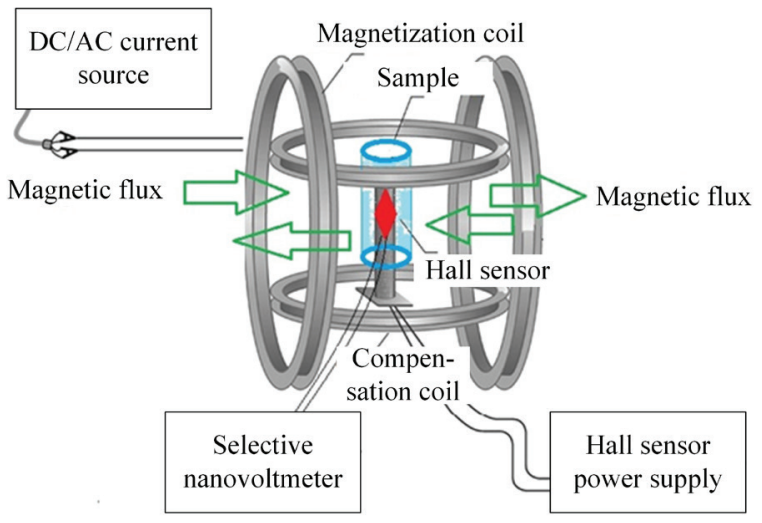

Figure 2 - Installation for measuring the attenuation coefficient of a permanent magnetic field

Table

\section{Helmholtz coil parameters}

\begin{tabular}{cccc}
\hline № & $\begin{array}{c}\text { Magnetic flux } \\
\text { direction axis }\end{array}$ & $\begin{array}{c}\text { Coil diameter, } \\
d, \mathrm{~m}\end{array}$ & $\begin{array}{c}\text { Conversion } \\
\text { factor, } k_{I \rightarrow H}\end{array}$ \\
\hline 1 & $Y$ & 0.40 & $2.24 \cdot 10^{-3}$ \\
2 & $X$ & 0.35 & $2.28 \cdot 10^{-3}$ \\
3 & $Z$ & 0.30 & $2.33 \cdot 10^{-3}$ \\
\hline
\end{tabular}

The installation has the ability to adjust its position in space to compensate for the Earth's magnetic field. To compensate it is necessary to install the three-coordinate Helmholtz coils in the optimal position achieving the minimum value of the potential difference on the sensitive element of the Hall sensor due to spatial manipulation.

It is necessary to calibrate the Hall sensor by setting the reference values of the potential difference over the entire range of magnetic fields with the step selected for the measurement before each measurement of the shielding efficiency. The change in the intensity of the external permanent magnetic field formed by the Helmholtz coils is carried out by changing the value of the constant current at the power source. After calibration the Hall sensor is placed in a protective case or covered with a 
cylindrical or flat shield keeping its position in space unchanged. The values of the potential difference on the sensor protected by the shield are recorded at the same values of the magnetic field strength. Shielding efficiency $E$ is often a dimensionless quantity that shows how many times the strength of an external magnetic field decreases when a shield is used. The calculation of the magnetostatic shielding efficiency is carried out according to the formula:

$E=\left(U_{0} / U_{x}\right)$,

where $U_{0}$ is the value of the potential difference (arithmetic mean) on the sensitive element of the Hall sensor without package (reference value); $U_{x}$ is the value of the potential difference (arithmetic mean) on the sensitive element of the Hall sensor when using a protective case.

The attenuation coefficient $k_{E}$ (or the efficiency expressed in decibels) is used to assess the effectiveness of shielding. $k_{E}$ can be estimated using formula (5):

$k_{E}=20 \lg \left(U_{0} / U_{x}\right)$ or $k_{E}=20 \lg E, \mathrm{~dB}$.

\section{Experimental results}

The weakening coefficients of the magnetic field were determined for two cylindrical specimens made of sheet permalloy (GOST 10160-75) and an aluminum cylinder coated with the same material $\left(\mathrm{Ni}_{80} \mathrm{Fe}_{20}\right)$ using the developed installation. Samples had equal overall dimensions (length of $120 \mathrm{~mm}$, a diameter of $45 \mathrm{~mm}$, and a thickness of the magnetic material of $0.5 \mathrm{~mm}$ ). An annealed permalloy foil was rolled into a cylinder of the corresponding diameter and spot welded to prepare a sheet sample. A coating was deposited on aluminum cylinder of appropriate size by electrolytic deposition as described in [15]. The shape of the sample is due to the fact that it matches the size of the housing of a wide range of photomultiplier tubes. $\mathrm{Ni}_{80} \mathrm{Fe}_{20}$ alloy was chosen as a reference sample as one of the most effective materials for protection against permanent magnetic field and electromagnetic radiation due to its high magnetic permeability [8]. High magnetic permeability provides effective shunting of the magnetic flux and, accordingly, a strong weakening of the magnetic field strength after passing through the coating (Figure 3).

The measurements of the magnetic field attenuation coefficient by the coating material were carried out in the range of magnetic fields from 0.1 to $9 \mathrm{mT}$. The results are shown in Figure 4.

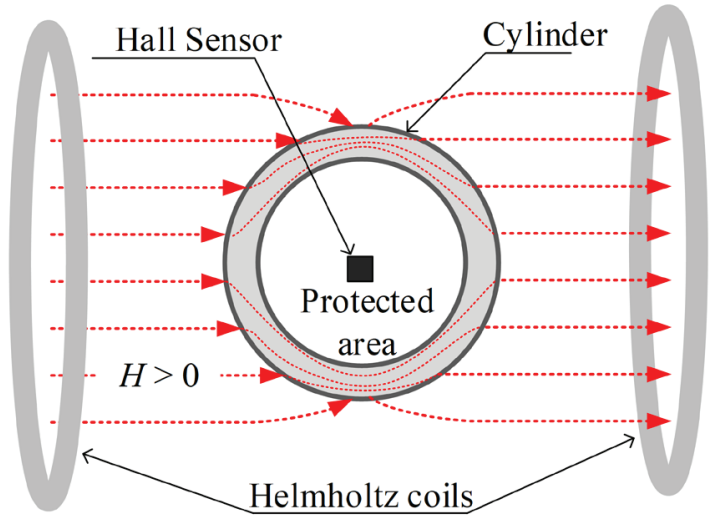

Figure 3-Schematic representation of the principle of shunting magnetic flux using a cylindrical body made of material with high magnetic permeability

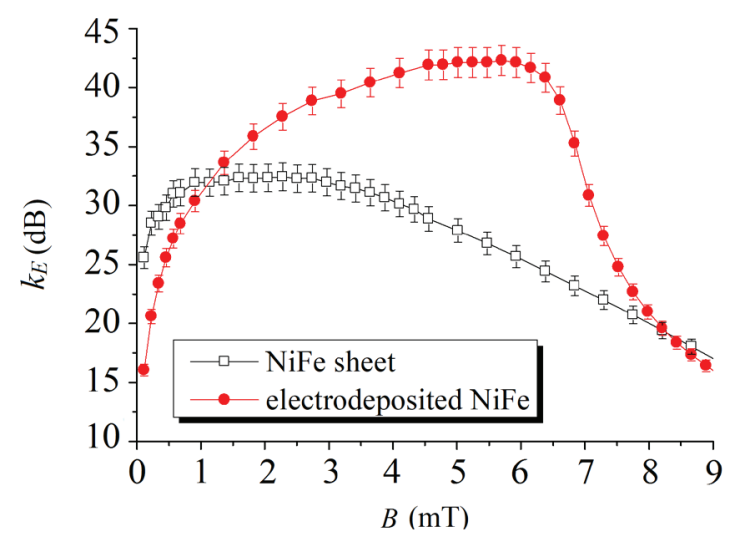

Figure 4-Results of the study of the magnetic field attenuation coefficient after passing through the package made of sheet permalloy and the package with the electrodeposited permalloy coating

It was found that in the range of weak magnetic fields (up to $1 \mathrm{mT}$ ) a sample of annealed sheet permalloy is a more promising material, since it demonstrates an attenuation of the order of 26-32 dB, which corresponds to 20-43 times, while the electrodeposited and unannealed sample in this the same range showed an increase in the attenuation coefficient from 16 to 31 times (or from 6 to 35 times). However, with a further increase in the magnetic field induction, no increase in the attenuation coefficient was observed for the sheet permalloy sample. The maximum value of $k_{E}$ for a sheet sample was $32.7 \mathrm{~dB}$ or 43 times. The attenuation coefficient increased to $42.3 \mathrm{~dB}$, which corresponds to 130 times. Thus, it is shown that in the range of magnetic fields up to $1 \mathrm{mT}$ the most significant factor for increasing the efficiency of magnetic flux attenuation is the high magnetic permeability of the protective material, 
which is characteristic of annealed alloys. In fields from $1 \mathrm{mT}$, the limiting factor for effective shunting of the magnetic flux is the closedness of the magnetic circuit or the continuity of the coverage in this case.

\section{Conclusion}

A unique measuring installation has been developed to determine the attenuation coefficient of the permanent magnetic field using protective package for electronic equipment. The installation will allow simulating the external effect of a permanent magnetic field in three-dimensional space to determine the effectiveness of protective materials and assess the performance of partings. The installation has a high accuracy in measuring weak magnetic fields due to the uniform magnetic flux generated by three pairs of Helmholtz coils and compensation of the Earth's magnetic field.

Certification of cylindrical package for protection against magnetostatic effects made of sheet permalloy and in the form of an electrodeposited coating on a cylindrical substrate has been carried out. It is shown that in weak fields (up to $0.1 \mathrm{mT}$ ), permalloy - annealed with in accordance with GOST 10160-75 - is a more effective material and weakens the magnetic field by 20-43 times due to high magnetic permeability. However with an increase in the magnetic field induction above $0.1 \mathrm{mT}$ the most important parameter providing effective attenuation is the closed magnetic circuit. Thus the continuous coating showed attenuation up to 130 times while the sheet alloy body had an attenuation coefficient of less than 43 times.

\section{References}

1. Chung D.D.L. Materials for electromagnetic interference shielding. Mater. Chem. Phys., 2020, vol. 255, p. 123587. DOI: $10.1016 /$ j.matchemphys.2020.123587

2. Geetha S., Satheesh Kumar K.K., Chepuri R., Rao K., Vijayan M., Trivedi D.C. EMI shielding: Methods and materials. A review. J. Appl. Polym. Sci., 2009, vol. 112, iss. 4, pp. 2073-2086. DOI: 10.1002/app.29812

3. Chung D.D.L. Electromagnetic interference shielding effectiveness of carbon materials. Carbon, 2001, vol. 39, iss. 2, pp. 279-285.

DOI: $10.1016 / \mathrm{S} 0008-6223(00) 00184-6$

4. Steven Reimers S. System and method for shielding electrical components from electromagnetic waves. Patent United States US6320123B1. Date: 2019-10-20.
5. Shenkman A., Sonkin N., Kamensky V. Active protection from electromagnetic field hazards of a high voltage power line. HAIT J. Sci. Eng. B., 2005, vol. 2, pp. 254-265.

6. Zhang Q., Liang Q., Zhang Z., Kang Z., Liao Q., Ding Y., Ma M., Gao F., Zhao X., Zhang Y. Electromagnetic Shielding Hybrid Nanogenerator for Health Monitoring and Protection. Adv. Funct. Mater., 2018, vol. 28, p. 1703801.

DOI: $10.1002 / \mathrm{adfm} .201703801$

7. Sumner T.J., Pendlebury J.M., Smith K.F. Convectional magnetic shielding. J. Phys. D: Appl. Phys., 1987, vol. 20, p. 1095. DOI: 10.1088/0022-3727/20/9/001

8. Grabchikov S.S., Trukhanov A.V., Trukhanov S.V., Kazakevich I.S., Solobaya A.A., Erofeenko V.T., Vasilenkov N.A., Volkova O.S., Shakin A. Effectiveness of the magnetostatic shielding by the cylindrical shells. J. Magn. Magn. Mater., 2016, vol. 398, pp. 49-53. DOI: 10.1016/j.jmmm.2015.08.122

9. Trukhanov A.V., Grabchikov S.S., Solobai A.A., Tishkevich D.I., Trukhanov S.V., Trukhanova E.L. $\mathrm{AC}$ and DC-shielding properties for the $\mathrm{Ni}_{80} \mathrm{Fe}_{20} / \mathrm{Cu}$ film structures. J. Magn. Magn. Mater., 2017, vol. 443, pp. 142-148. DOI: $10.1016 /$ j.jmmm.2017.07.053

10. Ala G., Di M., Silvestre L. A simulation model for electromagnetic transients in lightning protection systems. IEEE Trans. Electrom., 2002, vol. 44, iss. 4, pp. 539-554. DOI: 10.1109/TEMC.2002.804773

11. Moglie F., Micheli D., Laurenzi S., Marchetti M., Primiania V.M. Electromagnetic shielding performance of carbon foams. Carbon, 2012, vol. 50, pp. 1972-1980. DOI: $10.1016 /$ j.carbon.2011.12.053

12. Unal E., Gokcen A, Kutlu Y. Effective electromagnetic shielding. IEEE Microw. Mag., 2006, vol. 7 , iss. 4, pp. $48-54$.

DOI: 10.1109/MMW.2006.1663989

13. Ishibashi K., Yoshioka T., Wakao S., Takahashi Y., Andjelic Z., Fujiwara K. Improvement of Unified Boundary Integral Equation Method in Magnetostatic Shielding Analysis. IEEE Trans. Magn., 2014, vol. 50, iss. 2, pp. 105-108, art. no. 7002404.

DOI: 10.1109/TMAG.2013.2282304

14. Reutov Yu.Ya. Physical interpretation of magnetostatic shielding. Russian Journal of Nondestructive Testing, 2000, vol. 36, pp. 117-126.

\section{DOI: $10.1007 / \mathrm{BF} 02759406$}

15. Zubar T.I., Fedosyuk V.M., Trukhanov A.V., Kovaleva N.N., Astapovich K.A., Vinnik D.A., Trukhanova E.L., Kozlovskiy A.L., Zdorovets M.V., Solobai A.A., Tishkevich D.I., Trukhanov S.V. Control of Growth Mechanism of Electrodeposited Nanocrystalline NiFe Films. J. Electrochem. Soc., 2019, vol. 166, iss. 6, pp. D173-D180. DOI: 10.1149/2.1001904jes 